\title{
Removal of Congo red from textile wastewater by ozonation
}

\author{
*P. Gharbani; S. M. Tabatabaii; A. Mehrizad
}

Department of Chemistry, Islamic Azad University, Ahar Branch, Ahar, Iran

Received 15 April 2008; revised 12 May 2008; accepted 18 July 2008

\begin{abstract}
Congo red, which has a complex molecular structure with various diazo aromatic groups, is widely used in textile industry as an anionic dye. The purpose of this study was to investigate the degradation of Congo red in laboratory solution which had the chemical properties of the rinse waters of textile manufacturing dye-houses and the samples with Congo red alone wastewater by ozonation and to optimize the reaction parameters such as $\mathrm{pH}$ and time which influence the efficiencies of total organic carbon, total kjeldahl nitrogen and chemical oxygen demand removal. Ozonation of Congo red dye were carried out in a semi-batch reactor with constant ozone flow rate and concentration of $23 \mathrm{~mL} / \mathrm{sec}$ and $13.6 \mathrm{mg} / \mathrm{L}$, respectively. Decolorization was complete within a few minutes of ozonation possibly due to the cleavage of chromophore groups. It was observed that its structural destruction occurs predominantly at higher pHs. The reduction of chemical oxygen demand and destruction of the dye was more than $60 \%$ and $42 \%$, respectively. Total kjeldahl nitrogen removal was accompanied by slight changes in nitrogen oxides. It can be deduced from the experimental results that: (a) the mineralization is very weak; (b) the reaction follows the indirect mechanism; i.e., the interaction of hydroxyl radicals with the dye and (c) the nitrification is rather predominant. Biological oxygen demand is declined in simulated alkalic and neutral samples respectively. At $13.6 \mathrm{mg} \mathrm{O}_{3} / \mathrm{L}$, the biological oxygen demand levels were significantly enhanced. This might be attributable to the enhancement of its biodegradation at alkaline pHs.
\end{abstract}

Key words: Biological factor, total organic carbon, chemical oxygen demand, azo dyes, decolorization, effluents

\section{INTRODUCTION}

Textile industry is one of the most important industries in last few decades. It is broadcasted that more than $60 \%$ of the dyes world production is consumed by textiles industries (Khadhraoui et al., in press). Designated as water soluble, it was estimated that $10-20 \%$ of dye was lost during the dyeing process and released as effluent (Zhiqiao et al., 2007). The reagents used in textile industry are very diverse in chemical composition. The non-biodegradability of textile wastewater is due to the high content of dyestuffs, surfactants and other additives, which are generally organic compounds of complex structure (Muthukumar et al., 2004). It is difficult to treat these wastewaters by conventional technologies (Faouzi et al., 2006). Moreover, different papers report that in most cases, biochemical oxygen demand/chemical oxygen demand ratio of the composite textile wastewater is around 0.25 implying the non-biodegradability of the organic matter therein (Arsalan et al., 2002; Ahmet et al., 2003; Azbar et al., 2004; Lopez et al., 1998). Among the used dyes, azo-dyes are the most commonly utilized

*Corresponding Author Email: parvingharbani@yahoo.com Tel./ Fax: +98426222 8211 reagents owing to the presence of the azo-group which confers to these chemicals a certain resistance to light, acids, bases and oxygen, the desired properties for clothes'makers (Hung Yee and Ming Chin, 2005; Jiangning and Tingwei, 2001). More than $53 \%$ of these commonly used azo-dyes are identified as nonbiodegradable compounds. As a consequence, wastewaters bearing such type of dyes are known to be highly resistant to the mostly widespread used conventional wastewater treatment method: the biological processes (Banat et al., 1996; Vandavivre et al., 1998; Razo-Flores et al., 1997). In the past several decades, the wastewater discharges by dye manufacturing and textile finishing industries has been a major environmental concern (Koch and Yediler, 2002; Sheng, 2000). This is primarily due to their strong color with high dissolved solids in addition to the presence of elevated levels of aromatic ring containing organic compounds, the carcinogenic pollutants (Sarasa and Cortes, 2002). Congo red dye is one of important azo dyes. It is colored substances have complex chemical structures and high molecular weights. The chemical structure is the sodium salt of benzidinediazo-bis-1- 
naphtylamine-4-sulfonic acid. The dye's chemical structure and its main characteristics are shown in Fig. 1. It is highly soluble in water and persistent in the environment, once discharged into a natural environment. Thus, the study on Congo red is interesting not only for being possible pollutants of industrial effluents but also because it is a good model of complex pollutants (Tapalad et al., 2008). As to ozone, which is considered one of the powerful oxidizing agents (2.07V) (Alaton and Balcioglu, 2002), its application as a pretreatment for the improvement of wastewater biodegradability is thoroughly investigated (Eremektar et al., 2007; Gokcen and Ozbelge, 2005; Bila et al., 2005). In the recent years, ozonation is one of the most attractive alternatives for decolorize dye wastewater. Ozone is an extremely strong oxidant and reacts rapidly with most of organic compounds (Olivia et al., 2006). Ozone and hydroxyl radicals generated in aqueous solution are able to break the aromatic rings (Wei and Chi-Wai., 2000). The ozonation process left no chemical sludge in the effluent, combined color removal and COD reduction in one step and is easily operated. Moreover, the residual ozone naturally decomposed to oxygen (Jianging and Tingwei, 2001). It has been shown that ozone cleaves the conjugated bonds of azo-dyes chromophores, leading to color removal and enhancing the biodegradability of the treated wastewater (Eremektar et al., 2007; Selcuk, 2005). In contrast, other studies (Yediler et al., 2000) claim that short-term ozonation of a model aqueous azodye solution and dye-bath effluents from textile dyeing and finishing industry formed toxic compounds. These results were proved by testing the biodegradability of the effluent and bioluminescence tests (Yediler et al., 2000; Wang et al., 2002). Martins et al. (2006) have shown that in order to obtain high toxicity removal, longer ozonation periods with high ozone dozes have to be applied. Zhang et al. (2004) reported that the major disadvantage of using ozone is the possible formation of toxic byproducts even from biodegradable substances. The limitations of conventional chemical oxidation technique can be

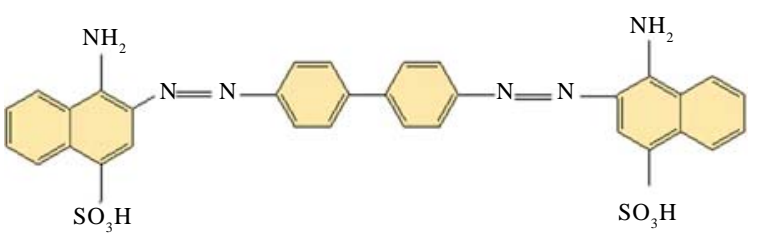

Fig. 1: Chemical structure of the studied molecule (molecular formula, $\mathrm{C}_{32} \mathrm{H}_{22} \mathrm{~N}_{6} \mathrm{Na}_{2} \mathrm{O}_{6} \mathrm{~S}_{2}$, molecular weight = $696.68 \mathrm{~g})$ overcome by the development of so-called advanced oxidation processes (AOPs) which involves the use of strong oxidizing agents $\left(\mathrm{O}_{3}, \mathrm{H}_{2} \mathrm{O}_{2}\right.$ or combined $\mathrm{O}_{3} / \mathrm{H}_{2} \mathrm{O}_{2}$ ) in the presence or absence of an irradiation source (Alaton and Balcioglu, 2002; Legini et al., 1993). It is also possible to utilize natural processes such as flocculation to remove dissolved metals (Karbassi, et al., 2008; Karbassi and Saeedi, 2008; Karbassi et al., 2007). In principle, AOPs generate very powerful and non-selective oxidizing agent, the hydroxyl radical $\left(\mathrm{OH}^{\circ}\right)$ for the destruction of refractory and hazardous pollutants found in groundwater, surface water and industrial wastewaters, respectively. The treatment of reactive and direct dyes in aqueous solutions via different AOPs has been extensively studied (Balcioglu and Arslan,1999; Chen et al., 1999; Chun and Yizhong, 1999). However, the advanced oxidation of direct and reactive dye bath effluents is rather limited to a smaller number of investigations (Arslan et al., 1999; Uygur and Kok, 1999). The present study focuses on the comparative analyses of the treatment of anionic direct dye in simple solutions and simulated exhausted dye bath liquors prepared from Congo red in different dyeing formulations. Thus this investigation is also aimed to obtain chemical and environmental data as COD, TKN, TOC or BOD for Congo red when its molecular deterioration is caused by ozone injection alone as an AOP technique. This research has been down at Islamic Azad University, Tabriz Branch on 2006.

\section{MATERIALS AND METHODS}

\section{Materials}

Congo red $\left(\mathrm{C}_{32} \mathrm{H}_{22} \mathrm{~N}_{6} \mathrm{Na}_{2} \mathrm{O}_{6} \mathrm{~S}_{2}\right.$; molecular weight: $696.66 \mathrm{~g} / \mathrm{mol}$ ) was purchased from Bayer, as labeled A200. Dye solutions were prepared by dissolving the dye in distilled water and concentration of $60 \mathrm{ppm}$ to simulate loaded textile wastewater. The Congo red solution has the initial $\mathrm{pH}$ of 7 . The $\mathrm{pH}$ was adjusted with hydrochloric chloride ( $\mathrm{HCl}$ ) and sodium hydroxide $(\mathrm{NaOH})$. Solvents are purchased from BHD.

\section{Ozonation reactor}

Ozone was produced by a discharge ozone generator model 500 from dry oxygen used as the feed gas provided by the Electronic Department of Baku National University. The ozone was produced by ozone generator with flow rate of $23 \mathrm{~mL} / \mathrm{s}$. and fed into the reactor through a porous glass diffuser located at the bottom of the reactor to produce fine bubbles. The oxygen was fed in constant flow rate and the input of ozone into the sample 


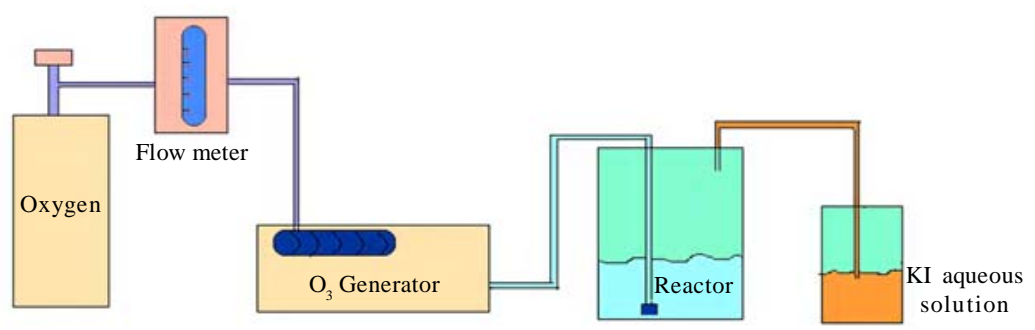

Fig. 2: Sketch of the experimental apparatus used for the ozonation

Table 1: Amount of the ozone absorbed at different time and oxygen flow rate. $\mathrm{C}\left(\mathrm{O}_{3}\right)=13.6 \mathrm{mg} / \mathrm{L}, \mathrm{C}$ (dye) $=60 \mathrm{mg} / \mathrm{L}$

\begin{tabular}{llllllll}
\hline $\begin{array}{l}\text { Time (min.) } \\
(\mathrm{mL} / \mathrm{sec})\end{array}$ & 0 & 5 & 10 & 15 & 30 & 45 & $\mathrm{O}_{2}$ flow rate \\
\hline & 0 & 1.214 & 4.28 & 5.2 & 9.31 & 10.6 & 10 \\
Absorbed $\mathrm{O}_{3}$ & 0 & 1.371 & 3.628 & 6.121 & 10.52 & 11.8 & 16 \\
$(\mathrm{mg} / \mathrm{L})$ & 0 & 1.714 & 4.8 & 7.52 & 12.97 & 13.6 & 23 \\
& 0 & 1.714 & 4.6 & 6.85 & 12.1 & 13.2 & 28 \\
\hline
\end{tabular}

solution was calibrated according to the time of injection. The excess ozone leaving the reactor was destroyed by sequential $20 \%$ KI traps incorporated to the reactor set-up as shown in Fig. 2. In this study, during the ozonation times, any excess of ozone was not identified through the sequential process mentioned previously. All ozonation experiments were conducted at room temperature and no reactor cooling was provided. The calibration data are shown in Table 1 as well as in Fig. 3. The value in time axes of whole Figs. are presented in this work are taken from the first row of the above mentioned table; i.e., the contact time of ozone. It should be noticed that the amount of the ozone absorbed can be simply obtained through either the time of oxygen injected on the its into the pilot reactor.

\section{Simulated direct dye bath effluent}

The direct dye (anionic Congo red ) and dye assisting chemicals were kindly supplied by an integrated textile manufacturing plant. The recipe mixture and the direct dye were used upon considering the international market share of their direct dyestuff content and colors mostly applied to the cotton fabrics in the dyeing stage. Usually 90-100 ppm of dyestuff and 1000 ppm of all applied dye assisting chemical remain in the exhausted direct dye bath liquor. The synthetic dye bath effluent was prepared about 60 ppm. The Congo Red solutions in distilled water alone, referred as laboratory sample herein, was first dissolved in doubly distilled water and then kept in cool room for $12 \mathrm{~h}$. prior to its use. The $\mathrm{pH}$ of solutions was adjusted with diluted sodium hydroxide or hydrochloric acid as when necessary. The $\mathrm{pH}$ values were selected in such a way as occurs in dying effluents of textile complexes; i.e., $7<\mathrm{pH}<11$.
Chemical and biochemical measurements

Oxidation advancement was followed by monitoring of chemical oxygen demand (COD), total organic carbon (TOC), total kjeldahl nitrogen (TKN) and pH. These parameters were analyzed according to the Standard methods described in the ASTM. Absorbance was determined using a Pharmacia Biotech Ultraspec 2000 UV/Vis spectrophotometer. Total organic carbon and total kjeldahl nitrogen were measured using a Skalar analyzer (Holland) and biological oxygen demand was measured using a BOD 5 Oxitop Box WTW (Germany) analyzer .

\section{RESULTS AND DISCUSSION}

\section{Experimental data}

Changes in $\mathrm{pH}$ were rather insignificant during any advanced oxidation of simulated dyehouse effluent. The $\mathrm{pH}$ was slightly declined in samples wherein the dye alone present since the solution was not highly buffered. In all treatment cases, the decline in the values of TOC, COD and UV -VIS absorbance is a general trend. The variation in $\mathrm{A} / \mathrm{A}_{0}$ percentages with the

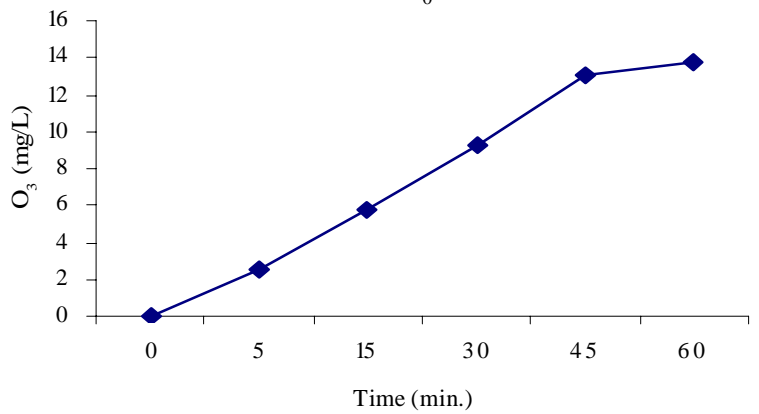

Fig. 3: The variation of ozone concentration versus the time of oxygen injection $\left(\mathrm{O}_{3}\right.$ flow $=23 \mathrm{~mL} / \mathrm{S}$. $)$ 
duration of ozone injection is shown in Fig. 4 at different pHs of Congo red. The variation of COD/COD $\%$ with the time of ozone injection is shown in Fig. 5 for the same samples. The TOC/TOC ${ }_{0} \%$ variation with the ozone doses (as calibrated to be $13.6 \mathrm{mg} / \mathrm{L}$ at the injection of 45 min.) is shown in Fig. 6 for the samples with different $\mathrm{pH}$ values. The variations of BOD5 and TKN with different injection time are shown in Tables 2 and 3 for samples with three different $\mathrm{pH}$ values, respectively.

\section{Analysis of data}

Ozone reacts with aromatic pollutants found in water and wastewater via two different pathways, namely direct molecular and indirect radical chain type reaction. The direct mechanism occurs mostly at neutral (and for less extend in acidic) chemical condition, whereas the indirect pathway is predominant at higher pHs (Shu and Huang, 1994). Hence, it can be deduced that the ozonation reaction pathway strongly depends on the characteristics of the sample to be treated, i.e. $\mathrm{pH}$, concentration of initiators, promoters and scavengers in the reaction medium. The data show that the effect of $\mathrm{pH}$ on treatment efficiency. The simulated direct dye bath effluent subjected to ozonation at the specific $\mathrm{O}_{3}$ doses had more or less the same consistency with respect to the $\mathrm{pH}$ of the samples. The same data was observed in the case of laboratory samples. From these data, it can be concluded that the $\mathrm{OH}^{0}$ scavengering does not take place in all samples under study. To conduct the ozonation processes at higher $\mathrm{pHs}$, the treatment performance of the ozonation should be further improved. In fact, Table 2 indicates that the biological efficiency increased as the doses of $\mathrm{O}_{3}$ increased. This is mainly because of a biodegradable organic species produced following the destruction of the molecular structure of Congo red by ozonation treatment. Again, the best results can be observed with the samples of $\mathrm{pH}=11.0$. All the cases mentioned previously are consistent with whole figures presented in the text. The removal percentages of dye at different chemical conditions in the terms of COD and TOC have been shown in Figs. 7 and 8, respectively.

\section{CONCLUSION}

In all treatment cases, decolorization of the samples was observed instantaneously in both simulated effluents and the samples contained the dye alone. This observation indicates that the color removal can be achieved in a simple process via both reaction pathways of ozone with Congo red. The higher molecular

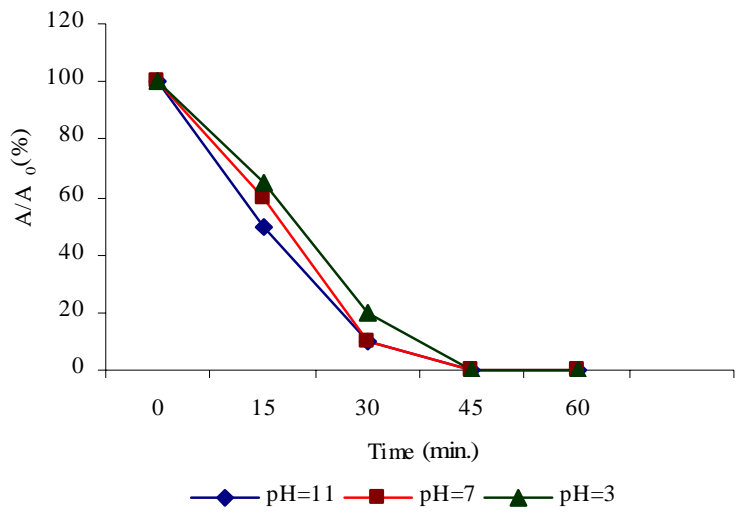

Fig. 4: Effect of pHs on percent UV absorption of Congo red at different ozonation time. $\mathrm{C}\left(\mathrm{O}_{3}\right)=13.6 \mathrm{mg} / \mathrm{L}$, $\mathrm{C}$ (dye) $=60 \mathrm{mg} / \mathrm{L}$

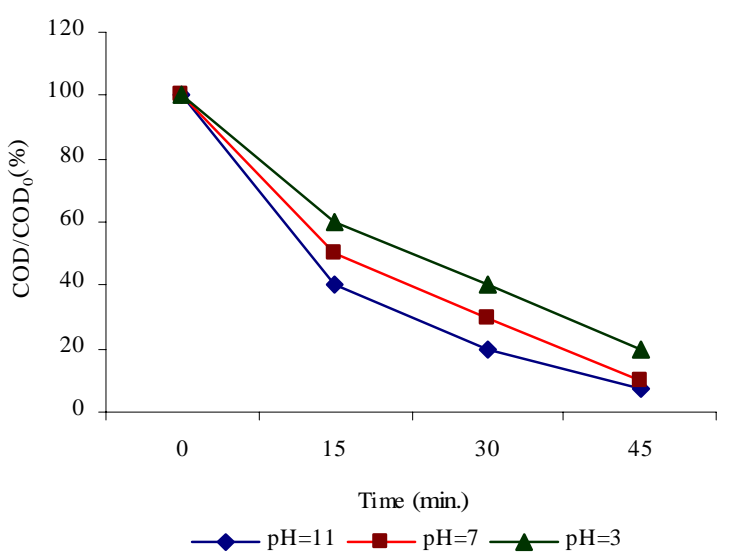

Fig. 5: Effect of pHs on percent COD removal of Congo red at different ozonation time. $\mathrm{C}\left(\mathrm{O}_{3}\right)=13.6 \mathrm{mg} / \mathrm{L}, \mathrm{C}$ (dye) $=60 \mathrm{mg} / \mathrm{L}$

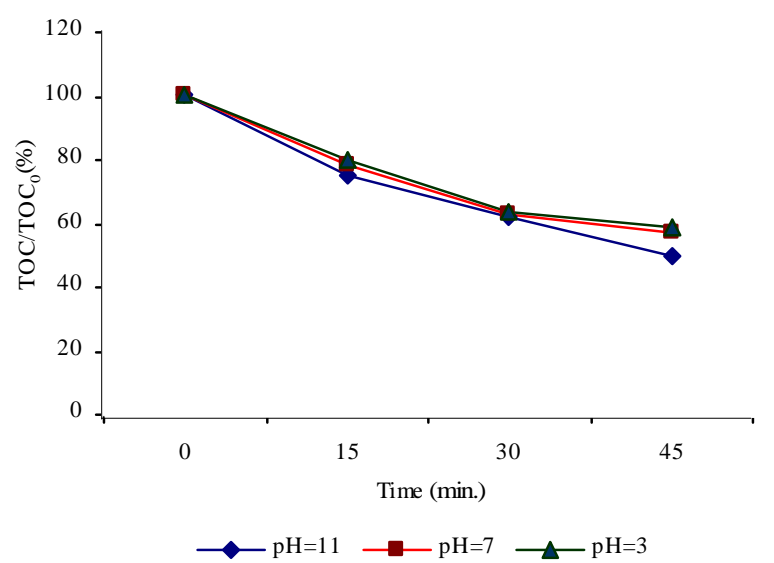

Fig. 6: Effect of pHs on percent TOC removal of Congo red at different ozonation time. $\mathrm{C}\left(\mathrm{O}_{3}\right)=13.6 \mathrm{mg} / \mathrm{L}, \mathrm{C}$ (dye) $=60 \mathrm{mg} / \mathrm{L}$ 


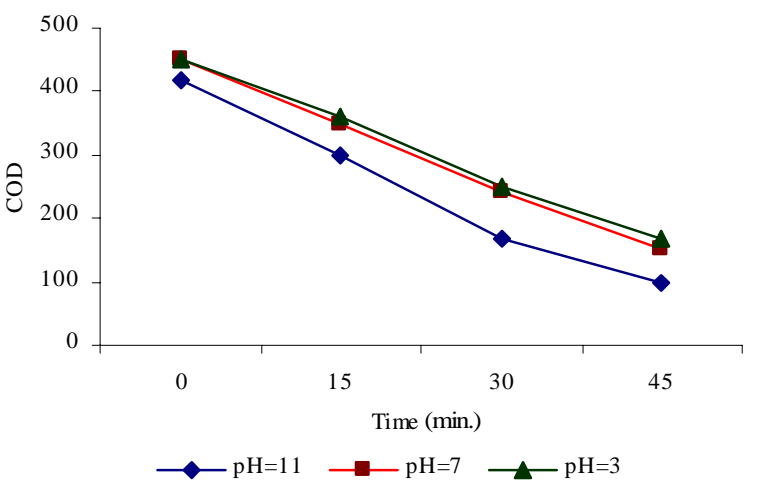

Fig. 7: Effect of pHs on COD removal of Congo red at different ozonation time. $\mathrm{C}\left(\mathrm{O}_{3}\right)=13.6 \mathrm{mg} / \mathrm{L}, \mathrm{C}$ (dye) $=60 \mathrm{mg} / \mathrm{L}$

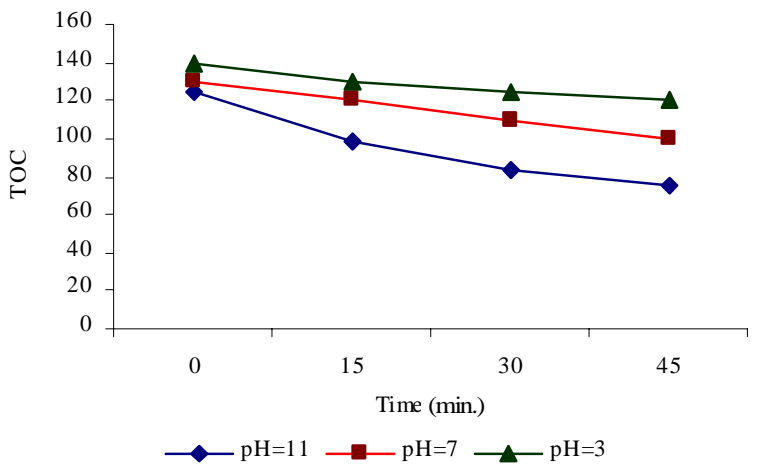

Fig. 8: Effect of pHs on TOC removal of Congo red at different ozonation time. $\mathrm{C}\left(\mathrm{O}_{3}\right)=13.6 \mathrm{mg} / \mathrm{L}, \mathrm{C}$ (dye) $=60 \mathrm{mg} / \mathrm{L}$

deterioration of Congo red takes place at alkaline condition, i.e., the indirect pathway of ozonation reaction. The ozonation process enhances the biodegradation efficiency due to the biodegradability of the products which were produced during the treatment. Therefore, it can be suggested that an optimal procedure for $\mathrm{AOP}_{\mathrm{S}}$ would be a pre-ozonation followed by a biodegradation process.

\section{ACKNOWLEDGEMENT}

The authors wish to thank Dr. Tajmir Riahi and Dr. Govindachary for their kind assistances during the preparation of the text and experiments.

\section{REFERENCES}

Ahmet, B.; Ayfer, Y.; Doris, L.; Nese, N.; Antonius, K., (2003). Ozonation of high strength segregated effluents from a woolen textile dyeing and finishing plant., Dyes Pigments, 58, 93-98.

Alaton, A.; Balcioglu, I. A., (2002). Advanced oxidation of
Table 2: Effect of pHs on BOD value of Congo red at different ozonation time. C $\left(\mathrm{O}_{3}\right)=13.6 \mathrm{mg} / \mathrm{L}, \mathrm{C}$ (dye) $=60 \mathrm{mg} / \mathrm{L}$

\begin{tabular}{lllll}
\hline $\mathrm{pH}$ & $\mathrm{BOD}_{5} / \mathrm{BOD}_{0}$ & $\mathrm{BOD}_{5} / \mathrm{BOD}_{15}$ & $\mathrm{BOD}_{5} / \mathrm{BOD}_{30}$ & $\mathrm{BOD}_{5} / \mathrm{BOD}_{45}$ \\
\hline 3 & 156 & 110 & 80 & 40 \\
7 & 160 & 170 & 210 & 140 \\
11 & 180 & 195 & 220 & 120 \\
\hline
\end{tabular}

Table 3: Effect of pHs on TKN value of Congo red before and after $45 \mathrm{~min}$. ozonation time. $\mathrm{C}\left(\mathrm{O}_{3}\right)=13.6 \mathrm{mg} / \mathrm{L}, \mathrm{C}$ (dye) $=60 \mathrm{mg} / \mathrm{L}$

\begin{tabular}{llll}
\hline $\mathrm{pH}$ & $\mathrm{TKN}_{0}$ & $\mathrm{TKN}_{45}$ & $\mathrm{TKN}_{45}-\mathrm{TKN}_{0}$ \\
\hline 3 & 123 & 108 & 15 \\
7 & 146 & 125 & 21 \\
11 & 151 & 114 & 37 \\
\hline
\end{tabular}

reactive dye bath effluent: Comparison of $\mathrm{O}_{3}, \mathrm{H}_{2} \mathrm{O}_{2} / \mathrm{UV}-\mathrm{C}$ and $\mathrm{TiO}_{2} / \mathrm{UV}-\mathrm{A}$ Processes., Water Res., 36 (5), 1143-1154.

Arslan, I.; Balcioglu, I. A.; Tukhanen, T., (1999). Oxidative treatment of simulated dyehouse effluent by UV and nearUV light assisted Fenton's reagent., Chemosphere, 39 (15), 2767-2783.

Arslan, I. A.; Balcioglu, I. A.; Bahnemann, D. W., (2002). Advanced oxidation of a reactive dye-bath effluent: comparison of $\mathrm{O}_{3}, \mathrm{H}_{2} \mathrm{O}_{2} / \mathrm{UV}-\mathrm{C}$ and $\mathrm{TiO}_{2} / \mathrm{UV}-\mathrm{A}$ processes., Water Res., 36, 1143-1154.

Azbar, N.; Yonar, T.; Kestioglu, K., (2004). Comparison of various advanced oxidation processes and chemical treatment methods for COD and color removal from a polyester and acetate fiber dying effluent., Chemosphere, 55 (1), 35-43.

Balcioglu, I. A.; Arslan, I., (1999). Degradation of commercial reactive dyestuffs by heterogeneous and homogenous advanced oxidation processes: A comparative study., Dyes Pigments, 43 (2), 95-108.

Banat, I. M.; Nigam, P.; Singh, D.; Marchant, R., (1996). Microbial decolorization of textiledye-containing effluents: a review, Bioresource. Tech., 58 (3), 217-227.

Bila, D. M.; Montalvao, A. F.; Silva, A. C.; Dezotti, M., (2005). Ozonation of landfill leachate: evaluation of toxicity removal and biodegrability improvement., J. Hazard. Mater. B, 117 (2-3), 235-242.

Chen, G.; Lei, L.; Yue, P. L., (1999). Wet oxidation of high concentration reactive dyes., Ind. Eng. Chem. Res., 38 (5), 1837-1843.

Chun, H.; Yizhong, W., (1999). Decolorization and biodegradability of photocatalytic treated azo dyes and wool textile wastewater., Chemosphere, 39 (12), 2107-2115.

Eremektar, G.; Selcuk, H.; Meric, S., (2007). Investigation of the relation between COD fractions and the toxicity in a textile finishing industry wastewater: effect of preozonation., Desalination, 211 (1-3), 314-320.

Faouzi, M.; Caizares, P.; Gadri, A.; Lobato, J.; Nasr, B.; Paz, R.; Rodrigo, M. A.; Saez, C., (2006). Advanced oxidation processes for thetreatment of wastes polluted with azoic dyes., Electrochem. Acta, 52 (1), 325-31.

Gokcen, F.; Ozbelge, T. A., (2005). Enhancement of biodegrability by continuous ozonation in Acid Red-151 solutions and kinetics modeling., Chem. Eng. J., 114, 99-104.

Hung Yee, S.; Ming Chin, C., (2005). Decolorization effects of 
six azo dyes by $\mathrm{O}_{3}, \mathrm{UV} / \mathrm{O}_{3}$ and $\mathrm{UV} / \mathrm{H}_{2} \mathrm{O}_{2}$ processes., Dyes Pigments, 65 (1), 25-31.

Jiangning, W.; Tingwei, W., (2001). Ozonation of aqueous azo dye in a semi-batch reactor., Water Res., 35, 1093-1099.

Karbassi, A. R.; Nouri, J.; Ayaz, G. O., (2007). Flocculation of heavy metals during mixing of Talar river water with Caspian Sea water. Int. J. Environ. Res., 1 (1), 66-73.

Karbassi, A. R.; Nouri, J.; Mehrdadi, N.; Ayaz, G. O., (2008). Flocculation of heavy metals during mixing of fresh water with Caspian Sea water. Environ. Geol., 53 (8), 1811-1816.

Karbassi, A. R.; Saeedi, M., (2008). Esturian capacity in removal of trace metals from contaminated river water, Southern Caspian Sea. Water Environ. J., doi: 10.1111/j.17476593.2007.00101.x

Khadhraoui, M.; Trabelsi, H.; Ksibi, M.; Bouguerra, S.; Elleuch, B., (In press). Discoloration and detoxicification of a Congo red dye solution by means of ozone treatment for a possible water reuse., J. Hazard. Mater.

Koch, M.; Yediler, A., (2002). Ozonation of hydrolyzed azo dye reactive yellow 84(CI). Chemosphere, 46 (1),109-113.

Legini, O.; Oliveros, E.; Braun, A. M., (1993). Photochemical processes for water treatment., Chem. Rev., 93 (2), 671698.

Lopez, A.; Ricco, G.; Mascolo, G.; Di Pinto, G.; Pssino, R., (1998). Biodegrability enhancement of refractory pollutants by ozonation: a laboratory investigation on azo-dyes intermediate., Water Sci. Tech., 38 (4-5), 239-245.

Martins, A. O.; Canalli, V. M.; Azevedo, C. M. N.; Pires, M., (2006). Degradation of pararosaniline (C.I. Basic Red 9 monohydrochloride) dye by ozonation and sonolysis., Dyes Pigments, 68 (2-3), 227-234.

Muthukumar, M.; Sargunamani, D.; Selvakumar, N.; Venkata Rao, J.; (2004). Optimisation of ozone treatment for color and COD removal of acid dye effluent using central composite design Experiment., Dye Pigments., 63 (2),127-134.

Oliva, S. P.; Soares, J. M.; António, V.; Manuel, F. R., (2006). Ozonation of textile effluents and dye solutions under continuous operation: Influence of operating parameters., J. Hazard. Mater., 137 (3), 1664-1673.

Razo-Flores, E.; Luijten, M.; Donlon, B.; Lettinga, G.; Field, J., (1997). Biodegradation of selectedazo dyes undermethanogenic conditions., Water Sci. Tech., 36 (6-7), 65-72.

Sarasa, J.; Cortes, S.; Ormand, P.; Gracia, R.; Ovelleiro, J. L., (2002). Study of aromatic by-products formed from ozonation of anilines in aqueous solution., Water Res., 36 (12), 30353044.

Sheng, H.; Cheng, L., (2000). Kinetic characteristics of textile wastewater ozonation in fluidized and fixed activated carbon beds., Water Res., 34 (3), 763-772.

Selcuk, H., (2005). Decolourization and detoxification of textile wastewater by ozonation and coagulation processes., Dyes Pigments, 64 (3), 217-222.

Shu, H. Y.; Huang, C. R., (1994). Decolorization of mono-azo dyes in wastewater by advanced oxidation process : A case study of Acid Red and Acid Yellow 23., Chemosphere, 29 (12), 2597- 2607.

Tapalad, T.; Neramittagapong, A.; Neramittagapong, S.; Boonmee, M., (2008). Degradation of Congo red dye by ozonation., Chiang Mai J. Sci., 35 (1), 63-68.

Uygur, A.; Kok, E., (1999). Decolorization treatments of azo dye wastewatecs including dichlorotriazinyl reactive groups by using advanced oxidation method., Color. Tech., 115 (9), 350-354

Vandavivre, P. C.; Biznchi, R.; Vesrtraete, W., (1998). Treatment and reuse of wastewater from the textile wet-processing industry: review of emerging technologies., J. Chem. Tech. Biotech., 72 (4), 289-302.

Wang, C. X.; Yediler, A.; Lienert, D.; Wang, Z. J.; Kettrup, A., (2002). Toxicity evaluation of reactive dyestuffs, auxiliaries and selected effluents in textile finishing industry to luminescent bacteria Vibrio fischeri., Chemosphere, 46 (2), 339-344.

Wei, C.; Ma, C. W., (2000). Quantitative prediction of direct and indirect dye ozonation kinetics., Water Res., 34 (12), 3153-3160.

Wu, J.; Wang, T., (2001). Ozonation of aqueous azo dye in a semi-batch reactor., Water Res., 35 (4), 1093-1099.

Yediler, A.; Lienert, D.; Koch, M.; Kettrup, A.; Germirli-Babuna, F.; Karatas, O., (2001). Appropriate technologies for the minimization of environmental impact from industrial wastewaters-textile industry, a case study (AZ.: II/72 146), Final Report, Volkswagen-Foundation, Germany.

Zhang, F.; Yediler, A.; Liang, X.; Kettrup, A., (2004). Effect of dyes additives on the ozonation process and oxidation byproducts: a comparative study using hydrolyzed C.I Reactive Red 120., Dyes Pigments, 60 (1), 1-7.

Zhiqiao, H.; Shuang, S.; Huamin, Z.; Haiping, Y.; Jianmeng, C., (2007). C.I.Reactive Black 5 decolorization by combined sonolysis and ozonation., Ultrasonics Sonachem., 14 (3), 298304.

\section{AUTHOR (S) BIOSKETCHES}

Gharbani, P., Ph.D. student in chemistry at Islamic Azad University, North Tehran Branch and is lecturer in the Department of Chemistry, Islamic Azad University, Ahar Branch, Ahar, Iran. Email: parvingharabani@yahoo.com

Tabatabaii, S. M., Ph.D., Lecturer in the Department of Chemistry, Islamic Azad University, Ahar Branch, Ahar, Iran. Email: samad_tabatabaei@yahoo.com

Mehrizad, A., M.Sc. Lecturer in the Department of Chemistry, Islamic Azad University, Ahar Branch, Ahar, Iran.Email: ali.mehrizad@yahoo.com

This article should be referenced as follows:

Gharbani, P.; Tabatabaii, S. M.; Mehrizad, A., (2008). Removal of Congo red from textile wastewater by ozonation. Int. J. Environ. Sci. Tech., 5 (4), 495-500. 